Syntax Literate: Jurnal Ilmiah Indonesia p-ISSN: 2541-0849 e-ISSN: 2548-1398

Vol. 6, No. 1, Januari 2021

\title{
KOMUNIKASI PENDIDIKAN DAN VOKASI DALAM MENINGKATKAN KUALITAS PENGETAHUAN ENTERPREUNERSIHIP PESERTA DIDIK SEKOLAH MENENGAH KEJURUAN
}

Rico, Rika Apriany Sukmana, M. Irpan dan Muzahid Akbar Hayat

Universitas Islam Kalimantan Syekh Muhammad Arsyad Al Banjari Banjarmasin

Email: ricoaje1994@gmail.com, sukma.batola@gmail.com, irpanleska@gmail.com, dan m.akbarhayat@gamil.com

\begin{abstract}
Abstact
Vocational education in Indonesia is education to prepare students in strengthening skills and skills according to their talents and interests, realizing the embryo of a readyto-use workforce in the business world and industrial world, vocational education developed in vocational high schools in partnership with the business world and the industrial world in field work practice, as a forerunner to the preparation of students at a later date to open up jobs as entrepreneurs. Educational communication and entrepreneurship are integrated with each other in strengthening the skills and skills of students in Vocational High Schools. This research aims to contribute to vocational high schools and become a frame of thought for productive teachers in preparing new enterprenersip. The method used in this research is a descriptive research method with qualitative data properties that look for the theory, not test the theory or it can also be referred to as educational communication generating hypothesis and Interpreurship instead of hypothesis. The results showed that the knowledge of vocational high school students about entrepreneurship after participating in the training increased, from those who did not know anything about entrepreneurship to knowing what was meant by entrepreneurship.
\end{abstract}

Keywords: educational communication, vocational educationation and enterpreunersip.

\begin{abstract}
Abstrak
Pendidikan vokasi di Indonesia merupakan pendidikan mempersiapkan peserta didik dalam penguatan skill dan keterampilan sesuai bakat dan minat yang dimilikinya, mewujudkan cikal bakal tenaga kerja siap pakai dilapangan dunia usaha dan dunia industri, Pendidikan vokasi yang dikembangkan disekolah menengah kejuruan bermitra dengan dunia usaha dan dunia industri dalam praktik kerja lapangan, sebagai cikal bakal persiapan peserta didik di kemudian hari untuk membuka lapangan pekerjaan sebagai enterpreunersip. Komunikasi Pendidikan dan enterpreuhership saling terintegrasi dalam penguatan skill dan keterampilan peserta didik di Sekolah Menengah Kejuruan. Penelitian ini bertujuan untuk memberikan konstribusi pada sekolah menengah kejuruan dan menjadi kerangka berpikir bagi guru produktif dalam menyiapkan enterprenersip baru. Metode yang digunakan dalam penelitian ini adalah
\end{abstract}


metode penelitian deskriptif dengan sifat data kualitatif yang mencari teori, bukan menguji teori atau bisa juga disebut sebagai hypothesis generating komunikasi pendidikan dan Interpreurship bukan hypothesis. Hasil penelitian menunjukan Pengetahuan peserta didik Sekolah Menengah Kejuruan mengenai kewirausahaan setelah mengikuti pelatihan menjadi meningkat, dari yang tidak tahu sama sekali mengenai wirausaha menjadi tahu apa yang dimaksud dengan kewirausahaan.

Kata kunci: komunikasi pendidikan, pendidikan vokasi dan enterpreunersip

Coresponden Author

Email: ricoaje1994@gmail.com Artikel dengan akses terbuka dibawah lisensi

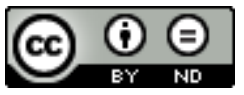

\section{Pendahuluan}

Abad 21 membuka persaingan kehidupan antar bangsa semakin meluas, dan berdampak langsung secara serius terhadap tuntutan peningkatan kualitas SDM melalui penyelenggaraan sistem dan model pendidikan yang bermutu, dan mampu menyiapkan SDM dalam menghadapi tantangan zaman. Menurut (Ijudin, 2014) pendidikan yang bermutu adalah pendidikan yang mampu menghasilkan lulusan yang memiliki kemampuan atau kompetensi, baik kompetensi akademik maupun kompetensi kejuruan, yang dilandasi oleh kompetensi personal dan sosial, serta nilai-nilai akhlak mulia yang keseluruhannya merupakan kecakapan hidup (life skill), pendiikan yang mampu menghasilkan manusia seutuhnya (manusia paripurna) atau manusia dengan pribadi yang integral (integrated personality).

Dalam pada itu kemudian pemerintah selalu berupaya pengendalian mutu pendidikan sekolah menengah kejuruan diperlukan langkah yang harus ditempuh adalah bagaimana menghasilkan lulusan yang memiliki mutu tinggi. Menurut ISO 9000 (Harbunangin \& Ronitua, 1995), mutu adalah keseluruhan karakteristik barang atau jasa yang menunjukan kemampuannya dalam memuaskan kebutuhan pelanggan. Mengacu pada rumusan tersebut untuk mengembangkan mutu pendidikan sekolah kejuruan (vokasi) dapat dirumuskan sebagai keseluruhan (karakteristik) kemampuan lulusan yang dapat memenuhi kebutuhan dunia kerja. Pengendalian mutu pendidikan, menyangkut pengendalaian komponenkomponen pendidikan yang menunjang terpenuhinya mutu pendidikan yang dibutuhkan dunia kerja. Komponen-komponen tersebut terdiri atas kebijakan mutu pendidikan, kurikulum, pembelajaran, fasilitas pendidikan, peserta didik, dan pendidik. Hasil dari proses pendidikan adalah kemampuan lulusan, sedang kriteria mutu lulusan adalah deskripsi kemampuan (kinerja) yang dituntut dunia kerja. Pengendalian mutu merupakan teknik dan operasional yang digunakan untuk memenuhi persyaratan mutu. Dengan 
demikian hal penting dapat dikemukakan disini, yaitu: bagaimana standar kemampuan (kinerja) lulusan sekolah kejuruan yang dituntut oleh dunia kerja? Dan bagaimana model pengedalian komponen-komponen pendidikan yang menunjang dihasilkannya lulusan yang memiliki kemampuan (kinerja) sesuai dengan tuntutan dunia kerja. Pendidikan Sekolah Menengah Kejurusan (SMK) Sekolah Menengah Kejuruan (SMK) merupakapan suatu satuan pendidikan jenjang pendidikan menengah yang mempersiapkan lulusannya untuk memasuki dunia kerja, seperti dirumuskan dalam PP Nomor 29 tahun 1990. Sekolah menengah kejuruan mengamban misi memenuhi kebutuhan tenaga kerja tingkat menengah yang profesional, mandiri, dan mampu mengembangkan diri sesuai dengan perkembangan ilmu pengetahuan dan teknologi guna mendukung proses industrialisasi. Lebih rinci tujuan dari sekolah menengah kejurusan adalah: 1. Menyiapkan siswa untuk memasuki lapangan kerja serta mengembangkan sikap profesional. 2. Menyiapkan siswa untuk memilih karir, mampu berkompetensi dan mampu mengembangkan diri. 3. Menyiapkan tenaga kerja tingkat menengah untuk mengisi kebutuhan dunia usaha dan industri pada saat ini maupun masa yang akan datang. 4. Menyiapkan tamatan agar menjadi warga negara yang produktif dan adaftif. Dari segi kuantitas keberadaan Sekolah Menengah Kejuruan telah cukup mendukung perkembangan industri, sebab dewasa ini telah ada sekitar 2.092 SMK Negeri dan Swasta di seluruh Indonesia, yang terbagai dalam 160 jenis program studi.

Tiap tahun sekitar 180.000 orang lulus dari SMK. Masalah utama yang dihadapi oleh pendidikan di SMK adalah mengenai kualitas. Persentase SMK yang berkualitas masih cukup kecil. Kualitas SMK berkaitan erat dengan ketersediaan peralatan dan bahan praktik, guru profesional serta pengelolaan pendidikan. Sebagian besar SMK yang ada belum memiliki peralatan dan bahan praktik yang memadai, walaupun telah cukup tersedia guru yang memiliki kemampuan profesional tetapi banyak dari mereka yang belum menunjukkan kinerja secara profesional, di samping masih adanya beberapa kelemahan dalam mengelolaan pendidikan. Peningkatan Kualitas (Mutu) Sekolah Menengah Kejuruan Peningkatan kualitas SMK sebagai penghasil tenaga-tenaga kerja terampil di bidang industri dan perusahaan merupakan syarat mutlak agar dapat menunjang percepatan laju pembangunan. SMK sebagai sekolah kejuruan memiliki karakteristik dan tuntutan tertentu. Jumlah siswa perkelas standar adalah 24 orang, baik untuk pelajaran teori maupun praktik. Karena $60 \%$ dari mata apelajaran di SMK bersifat praktik, maka setiap mata pelajaran yang memberikan latihan praktik menuntut peralatan dan bahan praktik yang memadai.

Keberadaan ruangan dan peralatan serta bahan praktik yang memadai, menuntut jumlah dan kualitas guru pembimbing praktik yang memadai pula. Penggunaan alat-alat praktik, terutama mesin-mesin membutuhkan guru pembimbing praktik (instruktur) profesional. Kemajuan dari bidang pendidikan tidak bisa terlepas dari peran serta guru dalam mendidik peserta didiknya (Aripin Hidayat, 2020). Kegiatan latihan praktik melibatkan banyak orang, baik siswa, guru, unsur pimpinan unit-unit praktik maupun asisten Toolman, juga menggunakan banyak peralatan dan bahan-bahan, semuanya itu 
membutuhkan sisten pengendalian yang efektif dan efisien. Tersedianya peralatan dan bahan praktik yang mencukupi, dengan bimbingan dari guru-guru pembimbing praktik profesional yang intensif, yang berlangsung dalam sistem pembelajaran yang terkelola dan dikendalikan dengan efektif dan efisien, akan dapat menghasilkan lulusan SMK yang memiliki keterampilan tinggi, dan siap memasuki dunia kerja. Memiliki kemampuan keterampilan yang tinggi harus ditopang oleh pribadi dan moral yang kuat, yang memungkinkan mereka memiliki kemandirian dan pegangan nilai-nilai kemanusiaan yang kokoh. Peran LPTK Dalam Pengembangan Pendidikan Vokasi di Indonesia 44 secara ekspositori melalui pemberian bahan dalam bentuk ceramah di kelas, tetapi perlu dimiliki siswa melalui pemahaman dan penghayatan langsung dalam kehidupan dan berbagai bentuk kegiatan pembinaan siswa. Dalam pada itu pembinaan siswa diarahkan pada penguatan skill dan keterampilan seabagai bekal kedepan untuk bewirasusaha/enterpreunership.

Apakah yang dimaksud dengan entrepreneurship? Banyak yang memberikan pengertian secara sempit, yaitu hanya sebagai ketrampilan dan pengetahuan dalam hubungannya dengan membuka lahan bisnis yang baru. Pengertian entrepreneur yang dihubungkan langsung dengan dunia bisnis akan membatasi pengertian yang asli dari entrepreneurship. Istilah entrepreneur dari padanan kata dalam bahasa Inggris, dan berasal dari bahasa Perancis ENTREPRENDRE, yang artinya menjalankan, melakukan, dan berusaha. Dalam bahasa Indonesia diterjemahkan sebagai WIRAUSAHA. WIRA berarti gagah berani, Usaha berarti tindakan untuk mencapai suatu hasil. Jadi WIRAUSAHA adalah orang yang gagah berani atau perkasa dalam menekuni usaha untuk mencapai hasil.

Sedangkan sistem informasi yang berbasis komputer yakni Tersusun atas hardware, software, basisdata, telekomunikasi, manusia, dan prosedur yang dirancang untuk mengumpulkan, memanipulasi, menyimpan, dan memproses data menjadi informasi. Jadi hubungan entrepreneurship dengan sistem informasi dan komunikasi adalah entrepreneur menyadari bahwa faktor manusia sangat penting bagi kesuksesan bisnis. Bukan hanya karyawan tapi termasuk juga customer, business partner, strategic alliances dan elemen manusia lainnyalah yang membuat bisnis sukses atau hancur berkeping-keping. Maka komunikasi menjadi kunci kesuksesan dalam menciptakan hubungan yang harmonis.

Seorang entrepreneur mau berpikiran terbuka untuk mempelajari cara berkomunikasi efektif, baik secara tulisan maupun lisan. Demi komunikasi efektif, mereka tidak segansegan menginvestasikan uang dan waktu untuk mengambil kursus komunikasi, public speaking, computer, e-mail, neurolingusitic programming, search engine optimization yang berhubungan dengan komunikasi dengan prospek dan customer. Mereka mau mendengar, berpikiran terbuka, menjaga integritas dengan mengatakan secara jujur apa yang ada didalam pikirannya.

Komunikasi Pendidikan dan Enterpreuhership saling terintegrasi dalam penguatan skill dan keterampilan peserta didik di Sekolah Menengah Kejuruan, apalagi pemerintah 
sudah menetapkan kurikulum atau yang disebut KTSP Kurikulum 2013 terkait dengan Pendidikan Vokasi. Sebagai perbandingan, maka kita dapat melihat table berikut dibawah ini :

Tabel 1

Research Gap Peningkatan Komunikasi dan Kewirausahaan

\begin{tabular}{|c|c|c|c|c|}
\hline Research Gap & $\begin{array}{l}\text { Manfaat } \\
\text { Penelitian }\end{array}$ & $\begin{array}{c}\text { Tujuan } \\
\text { Penelitian }\end{array}$ & Hasil & Peneliti \\
\hline $\begin{array}{l}\text { Terdapat } \\
\text { perbedaan } \\
\text { dalam proses } \\
\text { penelitian } \\
\text { tetapi secara } \\
\text { umum } \\
\text { komunikasi } \\
\text { dan } \\
\text { kewirausahaan } \\
\text { dapat } \\
\text { memebrikan } \\
\text { efek positif } \\
\text { yang sangat } \\
\text { signifikan } \\
\text { didalam } \\
\text { pengembangn } \\
\text { diri pengusaha } \\
\text { maupun } \\
\text { mahasiswa. }\end{array}$ & $\begin{array}{l}\text { Memberikan } \\
\text { konribusi dalam } \\
\text { kerangka pikir } \\
\text { dan upaya } \\
\text { mahasiswa } \\
\text { dalam } \\
\text { pemgembangan } \\
\text { keanekaragaman } \\
\text { tumbuhan } \\
\text { menjadi } \\
\text { entrepreneurship } \\
\text { yang } \\
\text { berkwalitas. }\end{array}$ & $\begin{array}{l}\text { Menjelaskan } \\
\text { Pengaruh model } \\
\text { komunikasi } \\
\text { wirausaha, } \\
\text { pembelajaran } \\
\text { enterpreuship, } \\
\text { dan sikap } \\
\text { kewirausahaan } \\
\text { terhadap kinerja } \\
\text { usaha kecil } \\
\text { meubel kayu di } \\
\text { Kota Prepare. } \\
\text { Meningkatkan } \\
\text { keterampilan } \\
\text { dan kolaborasi } \\
\text { mahasiswa } \\
\text { semester } \\
\text { program studi } \\
\text { Pendidikan } \\
\text { Biologi dalam } \\
\text { pengembangan } \\
\text { entrepreneurship } \\
\text { keanekaragaman } \\
\text { tumbuhan }\end{array}$ & $\begin{array}{l}\text { Positif } \\
\text { Signifikan }\end{array}$ & $\begin{array}{l}\text { Muhammad } \\
\text { Syaipul Hayat } \\
\text { et al. (2019) }\end{array}$ \\
\hline
\end{tabular}

Berdasarkan table diatas terlihat hasil penelitan yang sangat bagus dalam pengembangan Enterpreunersip sehingga membuat peneliti tertarik untuk melakukan penelitian lebih lanjut bagaimana dunia pendidikan yang menarik khususnya di sekolah menengeh kejuruan jika berkolaborasi secara baik dengan program Enterpreunersip.

\section{Metode Penelitian}


Metode penelitian yang digunakan oleh peneliti yakni metode deskriptif dengan sifat data kualitatif yang mencari teori, bukan menguji teori atau bisa juga disebut sebagai hypothesis generating Komunikasi Pendidikan Dan Interpreurship bukan hypothesis testing. Ciri lain metode deskriptif-kualitatif adalah menitikberatkan pada observasi dan suasana alamiah (natural setting) dimana penulis bersifat sebagai pengamat (Ardianto, 2011). Pendekatan yang digunakan dalam peneltian ini adalah pendekatan kualitatif. Denzin dan Lincoln mengungkapkan bahwa penelitian pendekatan kualitatif merupakan penelitian yang menggunakan latar ilmiah, dengan maksud menafsirkan fenomena yang terjadi dan dilakukan dengan jalan melibatkan berbagai metode yang ada (Moleong, 2019). Pendekatan ini memberi kemudahan bagi peneliti untuk merekam, memantau, dan mengikuti proses suatu peristiwa atau kegiatan sebuah organisasi sebagaimana adanya dalam suatu kurun waktu tertentu dan selanjutnya diinterpretasikan untuk menjawab masalah penelitian.

Oleh Locke, Spriduso dan Silferman (Cresswell, 2016), "Qualitative research is interpretative research as such the blases, values and judgement of the researches become stated explicity in the research report. Such openness is considered to be useful and positive" Penelitian kualitatif adalah penelitian interpretatif dengan demikian nilai-nilai dan penilaian dari penelitian menjadi menyatakan kejelasan dalam laporan penelitian. Keterbukaan seperti itu dianggap bermanfaat dan positif.

Karakteristik penelitian kualitatif seperti yang dinyatakan oleh Bogdan dan Biklen antara lain: "(1) dilakukan pada kondisi yang alamiah, langsung ke sumber data dan peneliti adalah instrumen kunci; (2) bersifat deskriptif yang dimana data yang terkumpul berbentuk kata kata atau gambar, sehingga tidak menekankan pada angka; (3) lebih menekankan pada proses daripada produk atau outcome; (4) melakukan analisis data secara induktif; dan (5) lebih menekankan makna." (Sugiyono, 2016).

\section{Hasil dan Pembahasan}

Pendidikan vokasi memegang peran penting pada peningkatan mutu sumber daya manusia di berbagai negara, mulai dari Eropa hingga Asia. Bukan hanya itu, sertifikasi kompetensi pada tenaga kerja yang sesuai kebutuhan industri pun memegang peran penting dalam vokasi. Atase Dikbud KBRI di Singapura Enda Wulandari mengatakan vokasi juga memiliki peran penting dalam peningkatan SDM di negara tersebut, meski semula hanya dipandang sebelah mata. Apa yang dipelajari pada pendidika vokasi yakni dengan melihat ke arah ekonomi berkembang. "Jadi perencanaan dilakukan melihat ke depan berdasarkan diskusi dengan dunia industri, sehingga mereka tahu pelatihan apa yang dibutuhkan untuk lulusannya masuk dan mempertahankan kinerjanya.

Pendidikan vokasi dan dunia industri kini harus saling berhubungan. Harapannya, lulusan pendidikan vokasi nantinya bisa diserap oleh industri dunia. Menurut Direktur Jenderal Pendidikan Vokasi Kementerian Pendidikan dan Kebudayaan (Kemendikbud), 
Wikan Sakarinto, ada lima syarat minimal agar link dan cocok antara pendidikan vokasi dan dunia industri dapat terjadi. "Paket link and match itu setidaknya ada lima," ujar Wikan seperti dikutip dari laman Kemendikbud, Jumat (18/9/2020).

Apa saja syarat itu? Berikut ini 5 syarat yang dijabarkan oleh Dirjen Pendidikan Vokasi: 1. Link and match antara vokasi dengan dunia industri adalah pembuatan kurikulum bersama. Kurikulum tersebut harus disinkronisasi setiap tahun dengan industri. 2. Pihak industri wajib memberikan guru atau dosen tamu. Minimal proses dari dosen dan guru tamu ini dilakukan minimal 50 jam per semester. 3. Pemberian magang kepada siswa SMK dan mahasiswa vokasi dari industri yang dirancang bersama. Menurut Wikan, pihaknya mewajibkan magang minimal satu semester. "Jangan sampai tiba-tiba industri cuma disodori magang suruh terima saja, tidak dari awal sudah dirancang bersama," ucap Wikan. 4. Sertifikasi kompetensi. Kompetensi merupakan hal yang sangat penting untuk lulusan vokasi. Sertifikat dibutuhkan untuk menunjukan tingkat lulusan vokasi. 5. Komitmen menyerap lulusan sekolah vokasi oleh industri. "Paket link and match hingga level menikah yang kami rancang mengembangkan teaching factory. Jadi industri pengajaran masuk ke dalam kurikulum," jelasnya. Dengan konsep lima syarat tersebut, Tentu dengan peningkatan kompetensi siswa SMK melalui link and match antara pendidikan vokasi dengan dunia industri. "Kompeten artinya lulusan itu sudah berani bilang aku bisa apa, bukan ini ijazahku. Kalau dia bilang ini ijazahku, itu artinya dia (hanya) bilang aku sudah belajar apa," katanya, Wikan berharap lulusan SMK akan memiliki kompetensi yang dibutuhkan oleh industri.

\section{Pendidikan Sekolah Menengah Kejurusan (SMK)}

Sekolah Menengah Kejuruan (SMK) merupakapan suatu satuan pendidikan jenjang pendidikan menengah yang mempersiapkan lulusannya untuk memasuki dunia kerja, seperti dirumuskan dalam PP Nomor 29 tahun 1990. Sekolah menengah kejuruan mengamban misi memenuhi kebutuhan tenaga kerja tingkat menengah yang profesional, mandiri, dan mampu mengembangkan diri sesuai dengan perkembangan ilmu pengetahuan dan teknologi guna mendukung proses industrialisasi. Lebih rinci tujuan dari sekolah menengah kejurusan adalah:

1. Menyiapkan siswa untuk memasuki lapangan kerja serta mengembangkan sikap profesional.

2. Menyiapkan siswa untuk memilih karir, mampu berkompetensi dan mampu mengembangkan diri.

3. Menyiapkan tenaga kerja tingkat menengah untuk mengisi kebutuhan dunia usaha dan industri pada saat ini maupun masa yang akan datang.

4. Menyiapkan tamatan agar menjadi warga negara yang produktif dan adaptif.

\section{Peningkatan Kualitas (Mutu) Sekolah Menengah Kejuruan (SMK)}

Peningkatan kualitas SMK sebagai penghasil tenaga-tenaga kerja terampil di bidang industri dan perusahaan merupakan syarat mutlak agar dapat menunjang percepatan laju 
pembangunan. SMK sebagai sekolah kejuruan memiliki karakteristik dan tuntutan tertentu. Jumlah siswa perkelas standar adalah 24 orang, baik untuk pelajaran teori maupun praktik. Karena $60 \%$ dari mata apelajaran di SMK bersifat praktik, maka setiap mata pelajaran yang memberikan latihan praktik menuntut peralatan dan bahan praktik yang memadai. Penggunaan alat-alat praktik, terutama mesinmesin membutuhkan guru pembimbing praktik (instruktur) profesional. Kegiatan latihan praktik melibatkan banyak orang, baik siswa, guru, unsur pimpinan unit-unit praktik maupun asisten Toolman, juga menggunakan banyak peralatan dan bahan-bahan, semuanya itu membutuhkan sisten pengendalian yang efektif dan efisien. Tersedianya peralatan dan bahan praktik yang mencukupi, dengan bimbingan dari guru-guru pembimbing praktik profesional yang intensif, yang berlangsung dalam sistem pembelajaran yang terkelola dan dikendalikan dengan efektif dan efisien, akan dapat menghasilkan lulusan SMK yang memiliki keterampilan tinggi, dan siap memasuki dunia kerja. Memiliki kemampuan keterampilan yang tinggi harus ditopang oleh pribadi dan moral yang kuat, yang memungkinkan mereka memiliki kemandirian dan pegangan nilai-nilai kemanusiaan yang kokoh.

\section{A. Model Komunikasi}

Model komunikasi adalah gambaran yang sederhana dari proses komunikasi yang memperlihatkan kaitan antara suatu komponen komunikasi dengan komponen lainya. Penyajian model dalam bagian ini dimaksudkan untuk mempermudah memahami proses komunikasi dan melihat komponen dasar yang perlu ada dalam suatu komunikasi.

1. Model lasswell

Model komunikasi yang dikemukakan oleh Harold Laswell (Forsdale, 1981), seorang ahli ilmu politik dari Yale University. Dia menggunakan lima pertanyaan yang perlu ditanyakan dan dijawab dalam melihat proses komunikasi, yaitu who (siapa), says what (mengatakan apa), in which medium atau dalam media apa, to whom atau kepada siapa, dan dengan what effect atau apa efeknya.

Bila dilihat lebih lanjut maksud dari model lasswell ini akan kelihatan bahwa yang dimaksud dengan pertanyaan who tersebut adalah menunjuk kepada siapa orang yang mengambil inisiatif untuk memulai komunikasi.

Pertanyaan kedua adalah says what atau apa yang dikatakan. Pertanyaan ini adalah berhubungan isi komunikasi atau apa pesan yang disampaikan dalam komunikasi tersebut. Pertanyaan ketiga adalah to whom. Pertanyaan ini maksudnya menanyakan siapa yang menjadi audience atau penerima dari komunikasi atau dengan kata lain kepada siapa komunikator berbicara atau kepada siapa pesan yang ia ingin disampaikan diberikan. Pertanyaan yang keempat adalah through what atau melalui media apa. Yang dimaksud dengan media adalah alat komunikasi, seperti berbicara, gerakan badan, kontak mata, sentuhan, radio, televisi, surat, buku dan gambar. Pertanyaan yang terakhir adalah what effect atau efeknya dari komunikasi tersebut. Misalnya sebuah sekolah swasta membuat iklan untuk mengkomunikasikan bahwa mereka akan menerima murid baru. Sesudah iklan ini disiarkan beberapa hari, sudah 
berapa orangkah yang telah mendaftar untuk menjadi murid. Jumlah orang yang mendaftar ini adalah merupakan efek dari komunikasi.

2. Model Shannon

Model komunikasi lain yang banyak digunakan adalah model komunikasi dari Claude Shannon atau lebih dikenal dengan model Shannon Wever. Model ini berbeda dengan model Lasswell mengenai istilah yang digunakan bagi masing-masing komponen. Sumber informasi (Information Source). Dalam komunikasi manusia yang menjadi sumber informasi adalah otak. Pada otak ini terdapat kemungkinan pesan yang tidak terbatas jumlahnya. Tugas utama dari otak adalah menghasilkan suatu pesan dari berjuta-juta pesan yang ada.

a. Transmitter

Langkah kedua dari medel Shannon adalah memilih transmitter. Pemilihan transmitter ini tergantung pada jenis komunikasi yang digunakan. Kita dapat membedakan dua macam komuikasi yaitu komunikasi tatap muka dan komunikasi menggunakan mesin.

Pada komunikasi tatap muka yang menjadi transmitternya adalah alat-alat pembentukan suara dan dihubungkan dengan otot-otot serta organ tubuh lainnya yang terlibat dalam penggunaan bahasa nonverbal. Sedangkan pada komunikasi yang menggunakan mesin-mesin alat-alat komuniaksi yang berfungsi sebagai transmitter adalah alat itu sendiri seperti, telpon, radio, televisi, foto dan film.

b. Penyandian (Encoding) pesan

Penyandian (Ecoding) pesan diperlukan untuk mengubah ide dalam otak kedalam suatu sandi ang cocok dengan transmitter. Dalam komunikasi tatap muka signal yang cocok dengan alat-alat suara adalah berbicara. Signal yang cocok dengan otototot tubuh dan indera adalah anggukan kepala, sentuhan dan kontak mata.

Pada komunikasi yang menggunakan mesin, dimana alat-alat yang digunakan sebagai perluasan dari indera, penyandian pesan juga berasal dar tubuh tetapi diperluas melalui jarak jauh dengan transmitter. Misalnya radio adalah perluasan dari suara manusia, televisi perluasan dari mata dan begitu juga dengan alat komuikasi lainnya.

c. Penerima dan decoding

Istilah Shannon mengenai penerima dan decoding atau penginterpretasian pesan seperti berlawanan dengan istilah penyadian pesan.

Pada komunikasi tatap muka kemungkinan transmitter menyandikan pesan dengan menggunakan alat-alat suara dan otot-otot tubuh. Penerima dalam hal ini alat-alat tubuh yang sederhana yang sanggup mengamati signal. Misalnya telingan menerima dan menguraikan sandi pembicaraan, mata menerima dan menguraikan sandi gerakan badan dan kepala, kilatan mata dan signal lainnya yang dapat dilihat mata.

d. Tujuan (Destination) 
Komponen terakhir dari Shannon adalah destination atau tujuan yang dimaksud oleh si komunikator. Destination ini adalah otak manusia yang menerima pesan yang berisi bermacam-macam hal, igatan ata pemikiran mengenai kemungkinan dari arti pesan. Penerima pesan telah menerima signal mungkin melalui pendengaran, penglihatan, penciuman dan sebagainya kemudian signal itu diuraikan dan diinterpretasikan dalam otak.

e. Sumber gangguan (Noise)

Dalam model komunikasi Shannon ini terlihat adanya factor sumber gangguan pada waktu memindahkan signal dari transmitter kepada si penerima. Misalnya pada waktu anda berbicara dengan teman dijalan kedengaran suatu mobil lewat anak-anak berteriak yang semuanya itu mengganggu pmbicaraan anda sesaat dan gangguan itu dinamakan noise. Untuk menetralkan gangguan ini Shinnom mengemukakan empat cara seperti berikut:

1. Menambahkan kekuatan dari signal

2. Mengarahkan signal dengan tepat

3. Menggunakan signal lain

4. Redudansi

3. Model Scraumn

Wilbur Scraumn memberikan model proses komunikasi yang agak berbeda sedikit dengan dua model sebelumnya. Dia memperlihatkan pentingnya peranan pengalaman dalam proses komunikasi. Bidang pengalaman akan menentukan apakah pesan yang dikirimkan diterima oleh si penerima sesuai dengan apa yang dimaksudkan oleh si pengirim pesan. Schraumn mengatakan jika tidak ada kesamaan dalam bidang pengalaman, bahasa yang sama, latar belakang yang sama, kebudayaan yang sama, maka sedikit kemungkinan pesan yang diterima diinterpretasikan dengan benar.

Model ini sama dengan model-model sebelumnya yaitu memperlihatkan proses komunikasi yang satu arah dan tidak dua arah. Oleh karena Schraumn menyadari pentingnya balikan dalam komunikasi, akhirnya menyempurnakan model ini menjadi model dua arah.

4. Model Berlo

Model yang dikembangkan (Berlo, 1960) hanya memperlihatkan proses komunikasi satu arah dn hanya terdiri dari empat komponen yaitu sumber,pesan,saluran dan penerima atau receiver. Akan tetapi pada masing-masing komponen tersebut ada sejumlah factor kontrol.

Faktor ketrampilan, sikap, pengetahuan, kebudayaan, dan sistem sosial dari sumber atau orang yang mengirim pesan merupakan factor penting dalam menentukkan isi pesan, perlakuan, atau treatment dan penyandian pesan. 
Model komunikasi Berlo disamping menekankan komunikasi sebagai suatu proses, juga menekankan ide bahwa arti pesan yang dikirimkan pada orang yang menerima pesan bukan pada kata-kata pesan itu sendiri. Dengan kata lain dapat dikatakan bahwa interpretasi pesan terutama tergantung kepada arti dari kata atau pesan yang ditafsirkan oleh si pengirim atau si penerima pesan dan bukan pada apa yang ada dalam komponen pesan itu sendiri.

5. Model Seiler

(Seiler \& Rom, 1997) memberikan model komunikasi dua arah dan bersifat lebih universal. Menurut Seiler source atau pengirim pesan mempunyai empat peranan yaitu menentukan arti apa yang akan dikomunikasikan, menyandikan arti kedalam suatu pesan, mengirimkan pesan dan mengamati, dan bereaksi terhadap respon dari penerima pesan.

Model Seiler ini disamping menekankan pentingnya balikan juga menekankan pentingnya factor lingkungan dalam proses komunikasi yang dapat mempengaruhi hakikat dan kualitas dari komunikasi. Misalnya adalah mudah melakukan pembicaraan secara rutin atau pribadi pada lingkungan yang menyenangkan dari pada lingkungan yang hiruk pikuk dan tidak menyenangkan. Beberapa lingkungan kadang-kadang mempercepat proses komunikasi dan beberapa lingkungan seakan menghambat proses komunikasi.

\section{B. Komunikasi Pendidikan}

Dewasa ini istilah komunikasi sepertinya telah menjalar di segala sendi kehidupan . Komunikasi adalah suatu proses penyampaian berita dari suatu sumber berita kepada orang lain (Arikunto, 2008). Komunikasi menjadi bagian yang terintegrasi dan seolah tak bisa dipisahkan begitu saja di dalam kehidupan sehari-hari. Hal ini wajar mengingat hakikat manusia sendiri merupakan makhluk sosial yang dimana dalam kehidupannya selalu berhubungan dengan orang lain dalam memenuhi kebutuhannya. Komunikasi pendidikan atau sering disebut dengan humas pendidikan, dalam hal ini tentu saja pengertiannya berbeda.

Dalam bidang pendidikan komunikasi memegang peranan yang sangat penting sekali. Bisa dibayangkan sebuah lembaga atau institusi pendidikan yang tidak bisa menerapkan komunikasi yang baik maka akan mustahil akan dicapai hasil atau output yang maksimal. Komunikasi mempunyai fungsi sebagai penyampai pesan berupailmu pengetahuan, teknologi maupun strategi untuk memecahkan sebuah permasalahan. Dalam prakteknya komunikasi yang dilakukan tidak selalu berjalan lancar, hal ini dikarenakan kemampuan tiap orang untuk menerima dan memahami isi pesan tidak sama.

Begitu banyaknya pakar dan sarjana yang mendefinisikan komunikasi itu sendiri, maka akan membingungkan kita dalam memaknai komunikasi itu yang sebenarnya. Ada baiknya kita memahami hakikat komunikasi antar manusia yang sebenarnya. Istilah komunikasi pertama kali lahir dari bahasa latin Communis yang artinya membuat 
kebersamaan atau membangun kebersamaan antar dua orang atau lebih. Maka lahirlah beberapa definisi dari pakar antara lain: (Kincaid, Schramm, \& Setiadi, 1977) melahirkan definisi baru yang menyatakan bahwa, Komunikasi adalah suatu proses dimana dua orang atau lebih membentuk atau melakukan pertukaran informasi dengan satu sama lainnya, yang pada gilirannya akan tiba pada saling pengertian yang mendalam”. Sementara itu, ada definisi lain mengenai komunikasi misalnya pendapat (Dance, 1967) mendefinisikan komunikasi dalam kerangka kerja psikologi perilaku manusia yang luas melalui pendefinisian komunikasi manusia sebagai " pengungkapan respon melalui simbol-simbol verbal", dimana simbol-simbol verbal itu bertindak sebagai perangsang (stimuli) bagi respon yang terungkap tadi.

Setelah mengkaji definisi beberapa pendapat para ahli diatas, setidaknya dapat kita tarik benang merah bahwa komunikasi merupakan sebuah proses komunikasi yang dilakukan oleh dua manusia atau lebih yang terjadi secara dua arah. Komunikasi yang demikian dinamakan komunikasi interaksi. Jika interaksi tersebut dikaitkan dengan pencapaian tujuan pembelajaran, maka dinamakan interaksi educative. Sehingga dapat ditarik kesimpulan, komunikasi pendidikan adalah komunikasi yang terjadi dalam suasana pendidikan. Di sini komunikasi tidak lagi bebas, tetapi dikendalikan dan dikondisikan untuk tujuan-tujuan pendidikan.

Hovland, jenis dan Kelley seperti yang dikemukakan (Forsdale, 1981) adalah ahli sosiologi Amerika, mengatakan bahwa komunikasi adalah proses individu mengirim stimulus yang biasanya dalam bentuk verbal untuk mengubah tingkah laku orang lain, mereka mengganggap bahwa komunikasi merupakan suatu proses Ruben, Brent D. Ruben, (Ruben \& Stewart, 2013) memberikan definisi mengenai komunikasi manusia yang lebih komprehensif sebagai berikut: komunikasi manusia adalah suatu proses melalui individu dalam hubunganya, dalam kelompok,dalam organisasi dan dalam masyarakat menciptakan, mengirimkan dan menggunakan informasi untuk mengkoordinasi lingkunganya dengan orang lain. Disini komunikasi pendidikan dalam pembelajaran pada siswa tentunya dilakukan dengan pendekatan-pendekatan, agar lebih mudah dipahami oleh mereka, pendekatan tersebut bagian dari model pembelajaran berkomunikasi. Dalam penyampaian materi pembelajaran kepada peserta didik, ada beberapa faktor yang perlu dipertimbangkan, diantaranya adalah peserta didik, ruangan kelas, metode, dan materi itu sendiri. Untuk dapat mencapai tujuan yang telah ditetapkan pada suatu kegiatan pembelajaran, metode pembelajaran dan komunikasi harus mendapat perhatian khusus dalam setiap proses pembelajaran.

Kata komunikasi menurut Wilbur Sechramm (bahwa kata komunikasi berasal dari bahasa latin yaitu "Comunicatio", yang diterjemahkan dengan pemberitahuan, pemberi bagian, pertukaran, pergaulan, persatuan atau kerjasama yang dilakukan dengan berunding bermusyawarah yang bertujuan untuk mencapai suatu kesepakatan (Rosmawaty, 2010: 14). [16] Sedangkan menurut para ahli komunikasi, seperti Claude Shannon dan Warren Wever 
(Zamroni, 2009) memaknai komunikasi sebagai proses penyampaian informasi, ide, perasaan, dan keahlian melalui simbol-simbol, seperti kata-kata, gambar, bentuk, grafik dan simbol-simbol lainnya. Dari proses tersebut dapat disimpulkan bahwa komunikasi adalah sebuah proses interaksi hubungan seseorang (Andrian, 2017) dengan orang lain yang terjadi dalam ruang tertentu. Sedangkan entrepreneur atau kewirausahaan (entrepreneurship) sering diistilahkan dengan wiraswasta atau wirausaha. Secara etimologis kata wirausaha entrepreneur berasal dari bahasa kata entre, pre dan neur. Kata entre artinya masuk, kata pre berarti sebelum dan kata neur berarti pusat syarat. Jika diartikan secara bahasa mengandung pengertian sebagai sebuah proses berpikir untuk melakukan sesuatu mengatasi persoalan. Jadi dapat disimpulkan bahwa kewirausahaan (entrepreneurship) adalah suatu kemampuan dalam berpikir kreatif dan berperilaku inovatif yang dijadikan dasar, dalam mengelola sumber daya, tenaga penggerak, tujuan, proses dalam menghadapi tantangan hidup

Komunikasi Pendidikan Komunikasi pendidikan merupakan proses komunikasi yang unik karena didalamnya ada dimensi edukatif selain menyampaikan pesan yang berupa materi pembelajaran. Komunikasi pendidikan bukan sekedar komunikasi yang berlangsung dengan latar pembelajaran atau pendidikan melainkan didalamnya terkandung nilai-nilai pendidikan. Dalam proses pembelajaran pasti didalamnya ada komunikasi dalam setiap interaksi edukasi akan berlangsung proses komunikasi. Komunikasi antara anak dan orang tua dalam pembelajaran di rumah atau guru dan siswa di sekolah serta dosen dan peserta didik Sekolah Menengah Kejuruandi Sekolah Menengah Kejuruan (Iriantara, 2013).

Proses pembelajaran akan menghasilkan model pembelajaran yang bergerak dari ranah yang sama. Model ini berupaya memberi perhatian yang khusus dan mengoptimalkan kemampuan peserta didik melalui pendekatan psikologi belajar, teori belajar, komunikasi pembelajaran dan rekayasa hasil inovasi teknologi komunikasi dan informasi (Darmawan, 2012).

Komunikasi pendidikan adalah "aspek komunikasi dalam dunia pendidikan atau komunikasi yang terjadi pada bidang pendidikan”. Dengan demikian, posisi komunikasi hanya sebagai 'alat' yang berfungsi bisa diupayakan untuk membantu memecahkan masalah-masalah pendidikan. Komunikasi dalam pendidikan merupakan unsur yang sangat penting kedudukannya. Bahkan mempunyai peranan dalam menentukan keberhasilan suatu pendidikan. Orang sering mengatakan bahwa tinggi rendahnya suatu capaian mutu pendidikan dipengaruhi pula oleh faktor komunikasi (Yusup Hidayat, Fuad, \& Nurhidayati, 2018).

Kondisi ideal dalam pembelajaran perlu melalui proses yang baik dan terencana. Dengan demikian perlu dilakukan sebuah pendalaman dalam melakukan perencanaan pembelajaran. Hal tersebut ditujukan agar kompetensi dapat terwujud dengan proses yang tepat serta dapat dipetakan dengan pemetaan yang jelas. Kemudian dapat dikatakan bahwa dalam pelaksanaan pendidikan formal dan non formal, peranan komunikasi menjadi unsur yang dominan. Adapun bentuk komunikasi pendidikan dalam konteks ini yaitu kegiatan 
instruksional dalam proses pendidikan. lebih lanjut, menjelaskan bahwa proses instruksional itu sendiri merupakan peristiwa komunikasi yang dirancang khusus untuk tujuan perubahan perilaku pada pihak sasaran (peserta didik) secara tuntas sesuai dengan kemampuan, minat, dan nilai-nilai yang dianutnya. Di dalam proses pengubah perilaku individu, faktor komunikasi ini sama-sama mempunyai kedudukan yang amat menentukan.

Efek yang terjadi akan dapat terlihat pada setiap individu, apakah mengalami perubahan sikap dan perilaku atau tidak. Sikap memiliki tiga komponen, yaitu: (1) Komponen kognisi yang hubungannya dengan beliefs, ide dan konsep. Komponen kognitif dapat disamakan dengan pandangan (opini), terutama apabila menyangkut masalah yang kontroversial; (2) Komponen afeksi yang menyangkut emosional seseorang. Komponen afektif merupakan perasaan individu terhadap objek sikap dan menyangkut masalah emosi. Aspek emosional inilah yang biasanya berakar paling dalam sebagai komponen sikap dan merupakan aspek yang paling bertahan terhadap pengaruh-pengaruh yang mungkin akan mengubah sikap seseorang; dan (3) Komponen konasi yang merupakan kecenderungan bertingkah laku.

Komponen konatif atau komponen perilaku berisi tendensi atau kecenderungan untuk bertindak atau untuk bereaksi terhadap sesuatu dengan cara- cara tertentu. Komponen ini didasari oleh asumsi bahwa kepercayaan dan perasaan banyak mempengaruhi perilaku. Pengertian kecenderungan berperilaku menunjukkan bahwa komponen konatif meliputi bentuk perilaku yang tidak hanya dapat dilihat secara langsung saja, akan tetapi meliputi pula bentuk- bentuk perilaku yang berupa pernyataan atau perkataan yang diucapkan seseorang. Sikap pada hakikatnya adalah kecenderungan perilaku seseorang terhadap lingkungannya. Beberapa orang menganggap bahwa sikap terdiri dari kognitif, afektif dan behavioral.dalam buku psikologi komunikasi Jalaludin Rahmat mengemukakan bahwa sikap dipandang dalam komponen afekifnya karena komponen kognitif dimasukan dalam konsep kepercayaan, komponen behavioral dimasukan dalam faktor sosiopsikologis konatif yang terdiri dari kebiasaan dan kemauan (Rakhmat, 2008).

Kewirausahaan Kewirausahaan adalah suatu ilmu yang mengkaji tentang pengembangan dan pembangunan semangat kreativitas serta berani menanggung resiko terhadap pekerjaan yang dilakukan demi mewujudkan hasil karya tersebut (Fahmi, 2014). Kewirausahaan adalah kemampuan untuk melihat, dan menilai kesempatan-kesempatan bisnis, mengumpulkan sumbersumber data yang dibutuhkan guna mengambil keuntungan daripadanya dan mengambil tindakan yang tepat guna dan sukses (Daryanto, 2012). Wirausaha dijelaskan oleh para ahli melalui berbagai definisi. Wirausaha adalah wadah bagi kemandirian, wadah belajar sekaligus wadah mengeksplorasi berbagai hal terkait kapasitas dan kapabilitas masyarakat untuk menghadirkan kemajuan bagi diri dan lingkungannya (Purnomo, 2020). Dari sisi pembentukan karakter seorang wirausaha/enterpreneur, Sekolah Menengah Kejuruan sudah seharusnya menciptakan atmosfer yang dapat mendorong sikap mandiri bagi sivitas akademika. Hal ini dapat dicapai 
melalui; 1) Mengembangkan dan membiasakan unjuk kerja yang mengedepankan ide kreatif dalam berpikir dan sikap mandiri bagi peserta didik Sekolah Menengah Kejuruandalam proses pembelajaran (menekankan model latihan, tugas mandiri, problem solving, cara mengambil keputusan, menemukan peluang, dan seterusnya); 2) Menanamkan sikap dan perilaku jujur dalam komunikasi dan bertindak dalam setiap kegiatan pengembangan, pendidikan, dan pembelajaran sebagai modal dasar dalam membangun mental entrepreneur pada diri mahasiswa; dan 3) Para praktisi pendidikan juga perlu sharing dan memberi support atas komitmen pendidikan mental entrepreneurship ini kepada lembaga-lembaga terkait dengan pelayanan bidang usaha yang muncul di masyarakat agar benarbenar berfungsi dan benar- benar menyiapkan kebijakan untuk mempermudah dan melayani masyarakat (Direktorat Jenderal Pendidikan Tinggi, 2013). Identitas baru sebagai wirausaha yang memiliki dampak manfaat bagi masyarakat banyak menjadi ukuran hal baru yang keren bagi generasi milenial. Generasi muda saat ini akan memilih untuk berperan bagi masyarakat dengan idealismenya melalui beragam bisnis yang mereka selenggarakan (Kurniawan, 2014).

Hasil penelitian menunjukkan untuk menumbuhkan jiwa kewirausahaan maka harus diketahui dulu pengetahuan peserta didik Sekolah Menengah Kejuruan tentang kewirausahaan seperti apa. Berdasarkan hasil penelitian sebagian besar peserta didik Sekolah Menengah Kejuruan belum mengetahui pengertian dari kewirausahaan karena mayoritas peserta didik Sekolah Menengah Kejuruantidak mendapatkan matakuliah kewirausahaan di kampusnya. Setelah mengikuti pelatihan kewirausahaan sebagian besar peserta didik Sekolah Menengah Kejuruan menjadi tahu dan mengerti apa yang dimaksud dengan kewirausahaan, bagaimana cara menggali potensi usaha yang ada di daerah tempat tinggal mereka. Peserta didik Sekolah Menengah Kejuruan mampu memahami pentingnya karakter wirausaha dan secara spontan dan otomatis dapat bersikap seperti wirausahawan dan berdasarkan pemahamannya menjadikan karakter tersebut sebagai pola hidup dalam kesehariannya. Sebelum berbicara mengenai wirausaha, ada baiknya peserta didik Sekolah Menengah Kejuruan diperkenalkan dan disadarkan tentang pentingnya mereka memiliki tujuan hidup atau impian. Hal ini sangat penting ditekankan di awal pelatihan agar peserta didik Sekolah Menengah Kejuruan memiliki semangat untuk berprestasi dan bersungguh sungguh meraih impiannya. Sangat disayangkan bila seorang peserta didik Sekolah Menengah dan baru menyadari untuk apa mereka sebenarnya kuliah, dan lain-lain setelah mereka lulus. Kebanyakan lulusan perguruan tinggi menjadi pengangguran adalah akibat mereka tidak memiliki impian dan tidak bersungguh-sungguh untuk meraihnya. Oleh karena itu kegiatan awal adalah penekanan mengenai urgensi impian dalam hidup. (Azwar, 2003) bahwa seharusnya para lulusan melihat kenyataan bahwa lapangan kerja yang ada tidak memungkinkan untuk menyerap seluruh lulusan perguruan tinggi di Indonesia, para lulusan perguruan tinggi mulai memilih berwirausaha sebagai pilihan karirnya, mengingat potensi yang ada di negeri ini sangat kondusif untuk melakukan wirausaha. bahwa, 
kemudian untuk memulai menjadi seorang wirausaha, setiap peserta didik Sekolah Menengah Kejuruan harus memiliki impian yang kokoh yang dibangun tidak dalam waktu singkat. Urgensi impian ini semakin penting mengingat resiko dari wirausaha ini tidaklah kecil, bila peserta didik Sekolah Menengah Kejuruan tidak memiliki impian yang kokoh maka sangat mungkin baginya untuk cepat dirumuskan, maka kita akan merujuk kepada sebuah konsep yang bernama SMART (Direktorat Jenderal Pendidikan Tinggi, 2013). Sukses itu bukanlah sebuah kebetulan, namun sukses adalah by Design. Oleh karena itu impian yang kita buat harus SMART “Cerdas”, Apakah impian yang SMART itu? Impian yang SMART adalah Impian yang: Specific artinya Anda harus jelas mengenai apa yang anda inginkan, dengan demikian anda akan lebih mudah dalam membuat perencanaan. Measurable artinya impian haruslah terukur. Dengan demikian, anda akan tahu kapan impian anda telah tercapai. Achieveble artinya Impian anda harus dapat anda raih. Jika impian itu terlalu besar, anda perlu memecah impian itu menjadi impian yang lebih kecil dulu sebagai langkah awal atau bagian dalam pencapaian impian besar. Realistic artinya, impian Anda harus masuk akal. Sukses itu bukanlah sebuah kebetulan, namun sukses adalah by Design. Sikap memiliki tiga komponen, yaitu: (1) Komponen kognisi yang hubungannya dengan beliefs, ide dan konsep. Komponen kognitif dapat disamakan dengan pandangan (opini), terutama apabila menyangkut masalah yang kontroversial; (2) Komponen afeksi yang menyangkut emosional seseorang. Komponen afektif merupakan perasaan individu terhadap objek sikap dan menyangkut masalah emosi. Aspek emosional inilah yang biasanya berakar paling dalam sebagai komponen sikap dan merupakan aspek yang paling bertahan terhadap pengaruh-pengaruh yang mungkin akan mengubah sikap seseorang; dan (3) Komponen konasi yang merupakan kecenderungan bertingkah laku. Komponen konatif atau komponen perilaku berisi tendensi atau kecenderungan untuk bertindak atau untuk bereaksi terhadap sesuatu dengan cara- cara tertentu. Komponen ini didasari oleh asumsi bahwa kepercayaan dan perasaan banyak mempengaruhi perilaku. Sikap pada hakikatnya adalah kecenderungan perilaku seseorang terhadap lingkungannya. Beberapa orang menganggap bahwa sikap terdiri dari kognitif, afektif dan behavioral. Dalam buku psikologi komunikasi Jalaludin rahmat mengemukakan bahwa sikap dipandanf dalam komponen afekifnya karena komponen kognitif dimasukan dalam konsep kepercayaan, komponen behavioral dimasukan dalam faktor sosiopsikologis konatif yang terdiri dari kebiasaan dan kemauan. Sebagian besar informan setelah mengikuti pelatihan kewirausahaan menjadi paham dan mengerti bagaimana mereka harus membuat perencanaan terlebih dahulu sebelum mereka membuat sebuah produk untuk usaha. Proses kewirausahaan dari beberapa konsep yang ada, setidaknya terdapat enam hakekat penting kewirausahaan. Di antaranya: 1) Kewirausahaan adalah suatu nilai yang diwujudkan dalam perilaku yang dijadikan dasar sumber daya, tenaga penggerak, tujuan, siasat, kiat, proses, dan hasil bisnis; 2) Kewirausahaan adalah suatu kemampuan untuk menciptakan sesuatu yang baru dan berbeda (ability to create the new and different); 3) Kewirausahaan adalah 
suatu proses penerapan kreativitas dan inovasi dalam memecahkan persoalan dan menemukan peluang untuk memperbaiki kehidupan; 4) Kewirausahaan adalah suatu nilai yang diperlukan untuk memulai suatu usaha (start-up phase) dan perkembangan usaha (venture growth); 5) Kewirausahaan adalah suatu proses dalam mengerjakan sesuatu yang baru (creative), dan sesuatu yang berbeda (inovative) yang bermanfaat memberi nilai lebih; dan 6) Kewirausahaan adalah usaha menciptakan nilai tambah dengan jalan mengkombinasikan sumbersumber melalui cara-cara baru dan berbeda untuk memenangkan persaingan. (Direktorat Jenderal Pendidikan Tinggi, 2013). Berdasarkan keenam konsep diatas, secara ringkas kewirausahaan dapat didefinisikan sebagai sesuatu kemampuan kreatif dan inovatif (create new and different) yang dijadikan kiat, dasar, sumber daya, proses dan perjuangan untuk menciptakan nilai tambah barang dan jasa yang dilakukan dengan keberanian untuk menghadapi risiko. Sebelum peserta didik Sekolah Menengah Kejuruan memulai berwirausaha maka ada beberapa hal yang harus dipersiapkan diantaranya adalah Pilih bidang usaha yang harus diminati oleh peserta didik Sekolah Menengah Kejuruan dan memiliki hasrat dan pengetahuan di dalamnya. Kemudian perluas dan perbanyak jaringan bisnis dan pertemanan. Pilihlah keunikan dan nilai unggul dalam produk atau jasa anda. Tentukan, apakah ingin bersaing berdarah-darah di usaha web murah meriah, atau akan spesifik kepada desainnya, atau akan spesifik kepada faktor keamanannya atau kepada tingkat kesulitan dan kompleksitas pengelolaan databasenya. Jaga kredibilitas dan brand image. Setelah mengikuti pelatihan kewirausahaan hampir semua peserta didik Sekolah Menengah Kejuruan mau melakukan wirausaha untuk mendapatkan keuntungan baik secara materil maupun secara moril dengan memanfaatkan sumber daya alam dan sumber daya manusia yang ada di tempat tinggal masing-masing. Ada yang akan memulai usaha membuat keripik dari singkong, ada yang akan membuat usaha membuat keripik dari pisang dengan berbagai rasa ada yang akan memulai lagi usaha membuat kue yang sebelumnya pernah dilakukan ketika mereka sedang kuliah. Semua peserta didik Sekolah Menengah Kejuruan tampak bersemangat dan antusias mewujudkan keinginan mereka untuk mulai dan melanjutkan berwirausaha dengan mengikuti ketentuan ketentuan yang harus diperhatikan ketika akan memulai wirausaha. Kiat memulai wirausaha juga dapat diadopsi menurut seorang pakar bisnis sekaligus motivator yaitu Tum Desem Waringin. Berikut ini adalah langkah- langkah teknis yang dapat dilakukan untuk memulai bisnis: 1) Bangun Ide bisnis dengan menulis Impian dan hobby kita. Tuliskan sepuluh mimpi dan hobby kita, lalu seleksi menjadi tiga yang paling membuat kita sangat ambisius dan enjoy untuk menjalankannya. Seleksi lagi menjadi satu mimpi yang membuat kita menjadi harus untuk mewujudkannya. Sehingga satu mimpi tersebut benar-benar dijadikan sebagai Visi/Goal/Target yang harus diraih; 2). Berikan alasan yang sangat kuat untuk mewujudkan mimpi tersebut. Bayangkan kenikmatan apa yang akan kita dapat apabila mimpi tersebut terwujud dan kesengsaraan apa yang akan kita terima kalau mimpi tersebut tidak terwujud; 3) Mulai lah untuk mewujudkan mimpi tersebut dengan bertindak 
dan cari tema yang tepat dan tulis misi / Langkah pencapaian dan tuangkan menjadi konsep usaha yang jelas; 4) Lakukan riset baik di internet maupun di kenyataan sehari-hari, Visi dan Misi yang kita tulis harus terdefinisi dengan jelas, specific dan marketabel sesuai bidangnya; 5) Tuliskan dan rancang strategi yang akan dijalankan; 6) gunakan faktor pengungkit OPM (Other People's Money),OPE (Other People's Experience), OPI (Other People Idea), OPT (Other People's Time), OPW (other People's Work); 7) Cari pembimbing (pilih yang sudah sukses di bidang tersebut), untuk pembanding dan mengurangi resiko kegagalan dalam melakukan langkah- langkah pencapaian tujuan tersebut; 8) Buatlah sebuah TEAM yang kompak untuk membantu mewujudkan goal tersebut $\mathrm{T}=$ Together $\mathrm{E}=$ Everybody $\mathrm{A}=$ Achieve $\mathrm{M}=$ Miracle; 9) Optimalkan jaringan, relasi dan network yang kita punya untuk mencapai tujuan/visi kita tersebut; 10) Buat jaringan baru yang tak terhingga dengan membuat relasi dan silaturahmi sebanyakbanyaknya; 11) Gunakan alat bantu untuk mempercepat pencapaian misal website, jejaring sosial, advertisement, promosi; dan 12). Buat sistem yang ideal untuk bisnis tersebut. $\mathrm{S}=$ Save, $\mathrm{Y}=$ Your, $\mathrm{S}=$ Self, $\mathrm{T}=$ Timing, $\mathrm{E}=$ Energy, $\mathrm{M}=$ Money (Direktorat Jenderal Pendidikan Tinggi, 2013).

\section{Kesimpulan}

Pengetahuan peserta didik Sekolah Menengah Kejuruan mengenai kewirausahaan setelah mengikuti pelatihan ini menjadi meningkat, dari yang tidak tahu sama sekali mengenai wirausaha menjadi tahu apa yang dimaksud dengan kewirausahaan. Keterampilan peserta didik Sekolah Menengah Kejuruan dalam merencanakan kewirausahaan setelah mengikuti pelatihan ini menjadi meningkat, dari yang tidak mengerti sama sekali mengenai perencanaan wirausaha menjadi mengerti dan mempraktekkan membuat perencanaan wirausaha. Keterampilan peserta didik Sekolah Menengah Kejuruan mengenai pelaksanaan wirausaha setelah mengikuti pelatihan ini menjadi meningkat, dari yang tidak pernah membayangkan suatu saat mereka akan bisa wirausaha menjadi terbayangkan bagaimana nantinya kalau mereka jadi pengusaha. 
Komunikasi Pendidikan dan Vokasi dalam Meningkatkan Kualitas Pengetahuan

Enterpreunersihip Peserta Didik Sekolah Menengah Kejuruan

\section{BIBLIOGRAFI}

Andrian, Bob. (2017). Manajemen Komunikasi Entrepreneur Usaha Mikro Berbasis Pondok Pasantren. Ilmu Dakwah: Academic Journal for Homiletic Studies, 11(1), $133-150$.

Ardianto, Elvinaro. (2011). Metodologi penelitian untuk public relations kuantitatif dan kualitatif. Bandung: Simbiosa Rekatama Media.

Arikunto, Suharsimi. (2008). Penelitian Tindakan Kelas, Jakarta: PT. Bumi Aksara.

Azwar, Saifuddin. (2003). Metode Penelitian Cetakan Ke-enam. Yogyakarta: Penerbit, Pustaka Pelajar.

Berlo, David K. (1960). The Process of Communication: An Introduction to Theory and. Practice (New York: Holt, Rinehart and Winston, 1960), 14.

Cresswell, John. (2016). Research design: Pendekatan metode kualitatif, kuantitatif, dan campuran (Edisi 4). Yogyakarta: Pustaka Pelajar.

Dance. (1967). The Physicial Best Teachers Guide. Human Kinetics.

Darmawan, Deni. (2012). Inovasi Pendidikan: Pendekatan Praktik Teknologi Multimedia dan Pembelajaran. Online. Bandung: PT. Remaja Rosdakarya.

Daryanto, Mulyo Rahardjo. (2012). Model pembelajaran inovatif. Yogyakarta: Gava Media.

Fahmi, Irham .. (2014). (2014). Analisa Kinerja Keuangan. Bandung: Alfabeta.

Forsdale. (1981). Perspectives on Communication. New York: Random House.

Harbunangin, Butje, \& Ronitua, Harahap Pardamean. (1995). 111 Hal Penting tentang ISO 9000. Jakarta: Iron Damwin Santosa.

Hidayat, Aripin. (2020). Pengaruh Kompetensi dan Motivasi terhadap Kinerja Guru di Gugus II Kecamatan Jatiwaras Kabupaten Tasikmalaya. Jurnal Revolusi Indonesia, $1(1), 1-12$.

Hidayat, Yusup, Fuad, Fokky, \& Nurhidayati, Maslihati. (2018). Implementation of economic democracy principle in Islamic banking policies through Financial Services 
Rico, Rika Apriany Sukmana, M. Irpan dan Muzahid Akbar Hayat

Authority (FSA) in Indonesia. At-Taradhi: J Stu Eko, 8(2), 132-154.

Ijudin. (2014). Strategi Mutu Lembaga Pendidikan Melalui Pendidikan Karakter. Jurnal Penididikan Universitas Garut.

Iriantara, Yosal \&. Usep Syarifudin. (2013). Komunikasi Pendidikan. Bandung: Simbiosa Rekatama Media.

Kincaid, D. Lawrence, Schramm, Wilbur, \& Setiadi, Agus. (1977). Asas-asas komunikasi antara manusia. Lembaga Penelitian, Pendidikan dan Penerangan Ekonomi dan Sosial Jakarta.

Kurniawan, Albert. (2014). Metode Riset untuk Ekonomi dan Bisnis. Bandung: Alfabeta.

Moleong, Lexy J. (2019). Metodologi penelitian kualitatif. Bandung: Alfabeta.

Purnomo, A. (2020). Dataset Penelitian Kewirausahaan di Indonesia Terindeks Scopus(1972-2019). Mendeley Data. Doi: Http://Dx. Doi. Org/10.17632/Kvbm8g9xm9, 1 .

Rakhmat, Jalaluddin. (2008). Psikologi Komunikasi, cet. Ke-26, Bandung: PT Remaja Rosdakarya.

Ruben, Brent D., \& Stewart, Lea P. (2013). Komunikasi dan perilaku manusia. Jakarta: Rajawali Pers.

Seiler, Michael J., \& Rom, Walter. (1997). A historical analysis of market efficiency: Do historical returns follow a random walk. Journal of Financial and Strategic Decisions, 10(2), 49-57.

Sugiyono. (2016). Metode Penelitian Kuantitatif, Kualitatif, dan R\&D. Bandung: Alfabeta.

Zamroni, Mohammad. (2009). Filsafat komunikasi. Yogyakarta: Graha Ilmu. 